\title{
PESAN NILAI-NILAI MOTIVASI PADA LIRIK LAGU ALBUM MONOKROM (KAJIAN SEMIOTIKA MODEL CHARLES SANDER PEIRCE)
}

\author{
Wahyu Mei Anggraeni, Yarno, R. Panji Hermoyo \\ Pendidikan Bahasa dan Sastra Indonesia, Universitas Muhammadiyah Surabaya \\ Wahyumei.1994@gmail.com
}

\begin{abstract}
ABSTRAK
Fokus penelitian ini adalah pesan makna nilai-nilai motivasi pada setiap lagu di album Monokrom. Metode dalam penelitian ini menggunakan penelitian kualitatif dengan pendekatan teknik analisis semiotika model Charles Sander Peirce. Subjek data penelitian ini adalah album Monokrom, dan objek data pada lirik lagu di di album Monokrom. Teknik pengumpulan data menggunakan dokumentasi dengan teknik simak dan teknik catat. Hasil penelitian menunjukkan bahwa pesan makna nilai-nilai motivasi pada album Monokrom meliputi 1) rasa empati terhadap orang lain dengan cara menghargai dan menghormati hak dan cara pandang mereka dari sisi yang berbeda. Rasa empati terdapat pada lagu Ruang Sendiri dan Tukar Jiwa. 2) rasa cinta terhadap kedua orang tua dan pasangan. Rasa cinta tersebut berupa perasaan jatuh cinta dan kasih sayang, tetapi rasa cinta tak selamanya berbuah manis. Tak sedikit rasa cinta tersebut berbuah rasa kecewa, seperti perasaaan kecewa dan dilema karena di antara keduanya memiliki tujuan akhir yang berbeda dalam menjalani sebuah hubungan kasih. Rasa cinta terdapat pada lagu Monokrom, Cahaya, Tergilagila, Langit Abu-abu, dan Pamit. 3) rasa optimisme, rasa yang harus dimiliki dan ditumbuhkan semua orang dalam dirinya, berupa rasa pantang menyerah dan kerja keras. Rasa optimisme ini yang akan membawa seseorang untuk tetap kuat dalam menjalani kehidupan. Rasa optimisme terdapat pada lagu Mahakarya, Manusia Kuat, dan Lekas.
\end{abstract}

Kata kunci: Album Monokrom, nilai-nilai motivasi, semiotika model Charles Sander Peirce.

\begin{abstract}
The research focused the message of the meaning of motivational values in each song on the Monokrom album. The method used qualitative research with the semiotic analysis technique approach of Charles Sander Peirce. The subject was the Monokrom album, and the data object was the song lyrics on the Monokrom album. Data collection techniques used documentation with note-taking techniques and notetaking techniques. The results showed that the message of the meaning of motivational values on the Monokrom album included 1) a sense of empathy for others by respecting and respecting their rights and perspectives from a different perspective. Empathy was found in the songs of Ruang Sendiri dan Tukar Jiwa. 2) love for both parents and partners. This love is a feeling of falling in love and affection, but love does not always bear sweet fruit. Not a little love is fruitful
\end{abstract}


disappointment, such as feelings of disappointment and dilemma because between the two have a different goal in undergoing a loving relationship. Love was found in the songs Monokrom, Cahaya, Tergila-gila, Langit Abu-abu, and Pamit. 3) a sense of optimism, a sense that must be owned and grown by all people in him, in the form of a sense of never giving up and hard work. This sense of optimism would bring someone to stay strong in living life. A sense of optimism was found in the songs Mahakarya, Manusia kuat, and Lekas.

Keywords: Song Lyric, Motivational Value, Charles Sander Peirce's Model Semiotics Study

\section{PENDAHULUAN}

Manusia sebagai makhluk hidup yang bermasyarakat tak terlepas dari kegiatan berinteraksi antarsesama. Salah satu bentuk interaksi yang dilakukan, yaitu dengan berkomunikasi. Proses komunikasi bertujuan untuk menyampaikan pesan dari seorang (komunikator) kepada orang lain (komunikan). Pesan yang disampaikan dapat berupa perasaan ataupun pikiran. Proses komunikasi memiliki banyak cara yang dapat dilakukan. Effendy (2009:7) memaparkan beberapa sifat komunikasi yakni: (1) Tatap muka (face-to-face), (2) Bermedia (mediated), (3) Verbal dapat berupa lisan dan tulisan/cetak, (4) Nonverbal, seperti kial/isyarat badaniah (gestural) dan bergambar (pictorial).

Proses komunikasi dapat dilakukan melalui media. Komunikasi bermedia adalah bentuk komunikasi yang menggunakan media sebagai sarana dalam menyampaikan pesan. Pentingnya peranan media dalam proses komunikasi terletak pada keefisiensinya dalam mencapai komunikan. Salah satu komunikasi bermedia, yaitu karya musik dalam bentuk lagu. Karya musik menjadi media komunikasi yang menyenangkan karena dapat menghibur dan menyampaikan pesan pada khalayak umum secara bersamaan.

Keberadaan musik di masyarakat sangatlah penting, terutama musik genre pop dan dangdut yang banyak diminati. Namun, belakangan ini perkembangan musik khususnya kedua genre tersebut mengalami penurunan dari segi pesan yang disampaikan. Pesan yang disampaikan serasa apa adanya tanpa sebuah proses pemaknaan yang lebih dalam. Hal tersebut terjadi karena dipengaruhi oleh gaya hidup dan kondisi sosial yang semakin terpuruk dalam segi psikologi. Karya-karya musik sekarang hanya mengedepankan musik yang ramai dan mengandalkan bentuk fisik 
yang indah dari musisi yang membawakannya, tanpa diiringi pesan makna yang berkesan.

Nilai estetika dari sebuah lagu yang semakin lama semakin pudar dapat membawa dampak buruk bagi pendengarnya. Dampak buruk tersebut disebabkan oleh lirik lagu yang memiliki makna kurang baik, sehingga secara tidak langsung meracuni pola pikiran. Pemikiran yang tertanami kata-lata yang kurang baik dapat berdampak pada perilaku seseorang.

Pentingnya lirik lagu pada karya musik karena melalui lirik pencipta lagu dapat menyampaikan perasaan atau pikirannya dengan kata-kata. Pesan yang disampaikan merupakan ekspresi seorang pencipta lagu menanggapi fenomena-fenomena yang terjadi di sekitarnya. Pemilihan kata-kata dalam menyusun lirik lagu merupakan hal yang tak mudah. Pencipta lagu harus memperhitungkan kata-kata yang tepat untuk menyampaikan makna yang diinginkan pada karyanya. Baik buruknya lirik lagu bergantung kondisi pencipta lagu, seperti kondisi sosial, psikologi, dan lainnya.

Tulus adalah salah satu pencipta lagu dan penyanyi di dunia musik Indonesia. Sejak 2011 hingga sekarang telah melahirkan tiga album karyanya sendiri dan dibantu mengarasemen oleh produsernya. Ketiga album itu, yakni Tulus (2011), Gajah (2014), dan Monokrom (2016). Pada album ketiganya mengandung pesan nilai-nilai kehidupan, yaitu nilai-nilai motivasi dalam hal cinta, optimisme, dan empati.

Motivasi merupakan nama lain dari membangkitkan motif. Motif dalam bahasa Inggris motive yang berarti suatu 'gerakan'. Gerakan itu merupakan bagian dari tingkah laku manusia. Pada bidang psikologi motif adalah suatu rangsangan yang menjadi dasar seseorang bertingkah laku untuk mencapai tujuan tertentu. Nilai motivasi dalam sebuah lagu dapat mempengaruhi seorang pendengar untuk ikut larut terhadap pemikiran sang pencipta lagu. Motivasi yang didapatkan dari sebuah menikmati sebuah lagu merupakan jenis motivasi internal dan eksternal bergantung ransangan yang ditimbulkan.

Lagu merupakan kesatuan dari lirik-lirik yang mewakili ekspresi dari seorang musisi ataupun pengambaran akan fenomena yang tengah terjadi di masyarakat. Kata lainnya, lagu merupakan tanda yang terdapat dalam lagu untuk menggungkapkan sebuah makna. Namun, Pemberian makna pada lagu tidak boleh semaunya, 
melainkan berdasarkan suatu ilmu atau sistem tanda yang disebut Semiotik. Semiotik adalah ilmu yang mempelajari tentang tanda. Mempelajari lagu secara semiotik berarti mengungkap tanda-tanda pada lirik lagu. Tanda tersebut merupakan sarana komunikasi ynag bersifat estetis, sehingga menimbulkan reaksi pendengar untuk memaknainya.

Pada penelitian ini objek yang akan diteliti menggunakan pendekatan semiotik berdasarkan teori yang dikemukakan oleh Charles Sander Peirce yang akan menelaah aspek linguistik dengan perluasan logika untuk mendeskripsikan makna dari lagu. Penelitian ini memfokuskan makna nilai-nilai motivasi pada lirik-lirik lagu di album Monokrom karya Tulus. Adapun tujuan penelitian ini untuk mengetahui dan mendeskripsikan makna motivasi pada lirik lagu karya Tulus di album Monokrom.

\section{METODE PENELITIAN}

Penelitian ini menggunakan metode analisis isi kualitatif dengan teori semiotika model Charles Sander Peirce. Eriyanto (2001: 337) analisis isi kualitatif menekankan pertanyaan “apa” pada analisis wacana, sehingga tidak hanya dapat mengetahui bagaimana isi teks dan pesan yang disampaikan. Analisis wacana lebih memfokuskan makna yang tersembunyi dari pesan, sehingga tidak hanya ditafsirkan dengan melihat permukaan pada teks.

Sumber data penelitian ini adalah lagu pada album Monokrom karya Tulus yang diunduh dari youtube pada tanggal 4 April 2018. Album Monokrom ini berisikan 10 lagu dalam bentuk MP4, yaitu Manusia kuat, Pamit, Ruang Sendiri, Cahaya, Langit Abu-abu, Monokrom, Tukar Jiwa, Tergila-gila, Mahakarya, dan Lekas. Objek dalam penelitian ini adalah lirik lagu pada setiap lagu di album Monokrom. Barthes (2010: 128) objek penelitian ini adalah semiotika pemaknaan terhadap teks lagu. Analisis tekstual dipahami sebagai analisis yang memiliki keluasan bahasa atau tafsiran, hingga teks dapat dibangun tanpa adanya akhir dengan merujuk pada teori kontemporer tentang teks. Analisis seperti ini membuat kita mampu memahami kekhasan masing-masing dari sebuah teks.

Teknik pengumpulan data menggunkan teknik dokumentasi. Sugiyono (2014: 240) menjelaskan bahwa dokumen dapat dijadikan data. Bentuk dari dokumen dapat berupa gambar, tulisan, atau karya-karya monumental dari seseorang. Data-data yang 
terkumpul dilanjutkan dengan menggunkan teknik simak. Teknik simak adalah salah satu jenis teknik pengumpulan data yang dilakukan dengan cara menyimak dari penggunaan bahasa, baik secara lisan maupun tulisan (Mahsun, 2005: 92). Dilanjutkan dengan menggunakan teknik catat, yaitu mencatat lirik-lirik lagu dengan kombinasi elemen-elemen lagu yang menciptakan sebuah makna.

Analisi data penelitian ini dilakukan berdasarkan semiotika model Charles Sander Peirce. Kriyantono (2009: 265) menyatakan bahwa teknik analisis Peirce berfungsi untuk menganalisis tenda-tanda komunikasi yang disebut dengan triangel meaning, yaitu hubungan antara tanda, interpretan, dan objek.

Langkah-langkah dalam menganalisis data, sebagai berikut:

1. Membagi bait lagu ke dalam beberapa berdasarkan intro, verse, bridge, reff, chorus, ending/coda, dan outro.

2. Membaca konteks lirik pada setiap bait lagu yang diciptakan Tulus

3. Memahami intonasi suara dan ketukan nada perbait lagu

4. Memaknai lirik lagu yang telah dibagi menjadi beberapa bagian lagu

5. Melakukan relevansi makna lagu dengan konteks yang ada saat ini.

\section{PEMBAHASAN}

Pada album Monokrom ini terdiri dari atas sepuluh data. Data-data tersebut menyiratkan nilai-nilai motivasi pada setiap lagunya. Nilai-nilai motivasi yang ada pada setiap lagu berdasarkan pada kebutuhan seperti cinta, optimisme, dan empati. Data tersebut telah dibagi sebagai berikut.

1. Cinta

Tabel 1. Nilai Motivasi dalam Bentuk Cinta

\begin{tabular}{|c|l|l|l|}
\hline No & Nilai motivasi & \multicolumn{1}{|c|}{ Judul lagu } & \multicolumn{1}{c|}{ Lirik lagu } \\
\hline 1 & Cinta berupa rasa & Langit Abu- & (chorus) \\
& kecewa & abu & $\begin{array}{l}\text { Daya pikat yang memang engkau punya } \\
\text { Sungguh-sungguh ingin aku lindungi }\end{array}$ \\
& & & Dan setelah luka-lukamu reda \\
& & & Kau lupa aku juga punya rasa \\
& & & Lalu kau pergi kembali dengannya \\
& & & Aku pernah menyentuhmu apa kau malu \\
\hline 2 & Cinta berupa rasa & Cahaya & (reff 1) \\
& jatuh cinta & & Bila aku pegang kendali penuh pada \\
\hline
\end{tabular}




\begin{tabular}{|c|c|c|c|}
\hline No & Nilai motivasi & Judul lagu & Lirik lagu \\
\hline & & & $\begin{array}{l}\text { cahaya } \\
\text { Aku pastikan jalanmu terang } \\
\text { Bila aku pegang kendali penuh pada } \\
\text { cahaya } \\
\text { Aku pastikan jalanmu terang }\end{array}$ \\
\hline 3 & $\begin{array}{l}\text { Cinta berupa rasa } \\
\text { kasih sayang }\end{array}$ & Monokrom & $\begin{array}{l}\text { (coda) } \\
\text { Lambang monokrom hitam putih } \\
\text { Aku coba ingat warna demi warna di } \\
\text { hidupku } \\
\text { Tak akan ku mengenal cinta } \\
\text { Bila bukan karna hati baikmu }\end{array}$ \\
\hline 4 & $\begin{array}{l}\text { Cinta berupa rasa } \\
\text { dilema }\end{array}$ & Pamit & $\begin{array}{l}\text { (verse) } \\
\text { Tubuh saling bersandar } \\
\text { Ke arah mata angin berbeda } \\
\text { Kau menunggu datangnya malam } \\
\text { Saat kumenanti fajar }\end{array}$ \\
\hline 5 & $\begin{array}{l}\text { Cinta berupa rasa } \\
\text { jatuh cinta }\end{array}$ & Tergila-gila & $\begin{array}{l}\text { (reff) } \\
\text { Kau menang menangkan hatiku } \\
\text { Kau buat ku tergila-gila } \\
\text { Kau pintar buat aku rindu } \\
\text { Kau buat ku tergila-gila, sayang uuu }\end{array}$ \\
\hline
\end{tabular}

2. Optimisme

Tabel 2. Nilai Motivasi dalam Bentuk Optimisme

\begin{tabular}{|c|c|c|c|}
\hline No & Nilai Optimisme & Judul lagu & Lirik lagu \\
\hline 1 & $\begin{array}{l}\text { Optimisme } \\
\text { berupa rasa } \\
\text { pantang menyerah }\end{array}$ & Manusia Kuat & $\begin{array}{l}\text { (coda) } \\
\text { Kau bisa Patahkan kakiku } \\
\text { Patah tangan Rebut senyumku } \\
\text { Hitamkan Putihnya hatiku } \\
\text { Tapi tidak mimpi-mimpiku }\end{array}$ \\
\hline 2 & $\begin{array}{l}\text { Optimisme } \\
\text { berupa rasa } \\
\text { semangat kerja } \\
\text { (kerja keras) }\end{array}$ & Mahakarya & $\begin{array}{l}\text { (reff) } \\
\text { Beri hati pada setiap kerja kerasmu } \\
\text { karya-karyamu } \\
\text { Beri hati pada setiap kerja kerasmu } \\
\text { karya-karyamu } \\
\text { (ending) } \\
\text { Mungkin kali ini lahirlah mahakaryamu }\end{array}$ \\
\hline 3 & Optimisme & Lekas & (verse) \\
\hline
\end{tabular}




\begin{tabular}{|l|l|l|l|}
\hline No & Nilai Optimisme & Judul lagu & \multicolumn{1}{c|}{ Lirik lagu } \\
\hline & berupa rasa & & Saat larut dalam sedih \\
& pantang menyerah & & Tak berhenti putari bumi \\
& & & Saat gentar hela nafas \\
& & & Tak berhenti cepatkan laju masa \\
\hline
\end{tabular}

3. Empati

Tabel 3. Nilai Motivasi dalam Bentuk Empati

\begin{tabular}{|c|l|l|l|}
\hline No & Nilai Empati & \multicolumn{1}{|c|}{ Judul lagu } & \multicolumn{1}{c|}{ Lirik lagu } \\
\hline 1 & $\begin{array}{l}\text { Empati berupa } \\
\text { menghargai dan } \\
\text { menghormati hak- } \\
\text { hak orang lain }\end{array}$ & Ruang Sendiri & $\begin{array}{l}\text { (chorus 1) } \\
\text { Baik buruk perubahanku tak akan kau } \\
\end{array}$ \\
& & $\begin{array}{l}\text { sadari (Kita berevolusi) } \\
\text { Bila kita ingin tahu seberapa besar rasa } \\
\text { yang kita punya } \\
\text { Kita butuh ruang }\end{array}$ \\
\hline 2 & $\begin{array}{l}\text { Empati berupa } \\
\text { menghargai dan } \\
\text { menghormati } \\
\text { penilaian orang } \\
\text { lain }\end{array}$ & Tukar Jiwa & $\begin{array}{l}\text { (chorus) } \\
\text { Seandainya satu hari bertukar jiwa } \\
\text { Kau akan mengerti dan berhenti } \\
\text { Bertanya tanya }\end{array}$ \\
\hline
\end{tabular}

Penelitian ini menggunkan metode analisis isi kualitatif dan teori segitiga makna milik Charles Sander Peirce yang bertujuan untuk mengetahui makna yang tersirat pada lirik lagu. Teori segitiga makna membagi setiap lagu menjadi tiga bagian, yaitu tanda, objek, dan interpretan. Tanda berupa lirik lagu sesuai struktur lagu, objek mengenai nilai-nilai motivasi, dan interpretan dari pemikiran Tulus yang menciptakan dan menyanyikan lagu-lagu tersebut.

Pada tabel 1, lima lagu mengandung makna nilai motivasi dalam benuk cinta. Cinta adalah salah satu komponen perasaan pada manusia tentang rasa sayang dan rasa terikat antara orang yang satu dengan lainnya, seperti keluarga, teman, dan kekasih (Sobur, 2013: 277). Di mana rasa ingin diterima keberadaanya oleh orang lain. Pada kelima lagu cinta terbagi menjadi 4 jenis, yaitu cinta berupa rasa kecewa, Cinta berupa rasa jatuh cinta, Cinta berupa rasa kasih sayang, dan Cinta berupa rasa dilema. Keempat jenis cinta tersebut akan dijelaskan sebagai berikut. 
1. Cinta berupa rasa kecewa.

Cinta tak selamanya memberikan rasa bahagia, tetapi ada kalanya cinta memberikan rasa kecewa. Rasa kecewa ada karena perasaan pada seseorang tidak dapat diterima keberadaannya oleh orang lain. Perasaan kecewa yang ingin disampaikan oleh Tulus pada lagu Langit Abu-abu. Lagu Langit Abu-abu bercerita tentang sebuah kekecewaan yang dirasakan seorang laki-laki ketika cinta mulai tumbuh dalam mengobati luka itu, tetapi ia hanya dijadikan sebagai tempat pelarian oleh teman perempuannya. Saat sedih melandanya, ia datang menghampiri. Namun, ketika kesedihan itu hilang, hilang pula keberadaanya

Pada lagu Langit Abu-abu ini Tulus ingin mengungkapkan tentang akibat dari kekecewaan yang dirasakan orang lain karena perbuatan orang lain yang hanya ingin melimpahkan kekesalan pada orang lain, atau hanya memanfaatkannya saja. Luka yang ditimbulkan dari perbuatan itu dapat menyakiti hati, terutama untuk masalah cinta dengan memberikan sebuah harapan yang palsu. Dari hal tersebut dapat memotivasi untuktidak bermain-main dengan urusan cinta.

2. Cinta berupa rasa jatuh cinta

Jatuh cinta adalah awal perasaan cinta tumbuh pada perasaan. Hal ini yang ingin disampaikan Tulus melalui dua lagu di album Monokrom, yaitu lagu Cahaya dan Tergila-gila.

a. Lagu Cahaya,

Lirik lagu Cahaya adalah aplikasi dari sebuah pemikiran Tulus mengenai gombalan cinta yang proporsional. Objek dalam lirik lagu ini mengenai rasa jatuh cinta diantara pertemanan. Lagu Cahaya menjadi salah satu motivasi tentang cinta yang disampaikan melalui lirik-lirik yang puitis dalam album Monokrom, yaitu rasa jatuh cinta yang tumbuh dalam sebuah hubungan pertemanan. Cinta adalah sebuah perasaan yang dimiliki semua orang untuk dapat memberikan rasa kasih dan juga diterima keberadaannya. Cinta inilah yang dapat mengubah seseorang ke arah yang lebih baik karena cinta dapat menjadi salah satu cara memotivasi seseorang dalam menjelaskan dan memperlihatkan kelebihan diri dengan tujuan untuk meraih 
hati ke lawan jenisnya. Pada lagu ini merupakan lagu tentang gombalan cinta yang masih dalam taraf proporsional dengan tidak melebih-lebihkan rayuan.

b. Lagu Tergila-gila

Kisah cinta yang semua orang pernah rasakan dihadirkan Tulus dalam lagu ini dengan lirik yang sederhana dan alunan musik yang ceria membuat pendengar dapat menangkap pesan lagu. Di mana saat cinta tumbuh dan bersemi pada hati kedua insan, cinta tersebut dapat membuat perasaan keduanya berbunga-bunga. Perasaan yang ingin selalu mengetahui keberadaan ataupun perasaan pasangannya. Hal ini yang ingin disampaikan Tulus pada lagu Tergila-gila. Lagu ini bercerita tentang getaran-getaran cinta yang tumbuh dan bersemi di antara dua insan. Rasa yang membuat keduanya candu akan asmara, dengan selalu memikirkan dan ingin berada di sisi pasangan. Kisah cinta yang dialami ini memberikan sebuah kekhususan dalam setiap ceritanya, walau ia pernah merasakan hal ini sebelumnya.

3. Cinta berupa rasa kasih sayang

Rasa kasih sayang dapat diwujudkan kepada siapa saja, sepeti keluarga. Lirik pada lagu Monokrom ini merupakan tanda yang diciptakan Tulus dari sebuah pengalaman yang dialaminya pada masa kecilnya. Pengalaman masa kecilnya merupakan interpetan dari Tulus yang melihat objek tentang rasa kasih sayang yang diberikan ibunya terhadap dirinya. Hubungan ketiga unsur, yaitu tanda, interpretan, dan objek menghasilkan sebuah nilai motivasi yang berdasarkan pada kebutuhan cinta berupa rasa kasih sayang. Nilai motivasi tentang rasa kasih sayang inilah yang ingin Tulus sampaikan pada pendengar lagu Monokrom ini. Nilai motivasi yang berdasarkan pada kebutuhan diri manusia berupa cinta yang diwujudkan dalam bentuk rasa kasih sayang. Rasa kasih sayang ini dapat diaplikasikan pada semua orang, seperti orang tua, teman, kekasih, dan persahabatan.

Dari pengalaman pada masa kecilnya inilah yang membuat Tulus menciptakan lagu Monokrom. Lagu yang Tulus persembahkan untuk ibunya yang sangat berjasa dalam hidupnya. Monokrom ini bercerita tentang kumpulan foto-foto yang masih berwarna hitam putih dengan cerita-cerita yang telah 
mengukir pribadinya. Cerita-cerita yang menjadi sebuah kisah masa kecil yang menjadi dasar mimpi-mimpi sekarang. Semua itu berawal dari kasih sayang ibunya terhadap Tulus. Rasa kasih sayang yang menjadi dasar pribadinya karena kasih sayang seorang ibu tak terbatas jumlahnya dan takkan pernah terganti. Bagi Tulus ibunya adalah segalanya karena ibunya orang pertama yang mengenalkan Tulus kecil mengenai berbagai macam jenis musik. Keluarga Tulus yang merupakan seorang pedagang memiliki sebuah toko, di sudut toko tersebut terdapat rak-rak kaset. Begitu banyak kaset dari lagu melayu hingga lagu barat ada di sana. Setiap Tulus kecil mendapatkan prestasi di sekolah ibunya selalu menghadiahkan sebuah kaset kesukaannya, tetapi jika tak berprestasi Tulus hanya dapat mendengarkan lagu-lagu pilihan ibunya. Tak hanya itu, saat menjelang tidur ibunya selalu menyanyikan lagu-lagu untuk Tulus kecil dalam menjemput bunga tidurnya. Rasa kasih sayang tersebut tumbuh dari sebuah kebutuhan tentang cinta bagi manusia.

4. Cinta berupa rasa dilema.

Cinta juga dapat menimbulkan perasaan dilema. Di mana pemikiran dan perasaan tak sama. Pada lagu Pamit menjelaskan tentang perasaan dilema pada hubungan kasih. Perasaan dilema dalam memilih untuk mengakhiri atau tetap bertahan. Akhirnya mengambil keputusan untuk mengakhiri hubungan kasih tersebut karena perbedaan-perbedaan di antra mereka tak dapat lagi disatukan. Hubungan antara objek (rasa dilema) dan tanda (lirik lagu), dan pemikiran Tulus (interpretan) ini menyiratkan sebuah motivasi dalam urusan cinta. Dengan adanya rasa dilema menjadikan diri seorang terdorong untuk berpikir dalam memutuskan hal mana yang baik untuk hubungan kasih yang dijalananinya, yaitu memilih untuk mengakhiri hubungan atau mempertahankan hubungan dengan segala risiko yang ada.

Pada tabel 2, tiga lagu mengandung nilai motivasi dalam bentuk optimisme. Optimisme adalah bagian dari komponen kepribadian yang penting untuk individu. Menurut Seligman (dalam Ghufron dan Risnawati, 2010: 96) menjelaskan bahwa optimisme merupakan sudut pandang seseorang yang secara keseluruhan dalam melihat permasalahan. Hal ini menjadikan seseorang berpikir 
positif dalam menyikapi suatu masalah, dengan meminimalkan rasa takut yang tumbuh pada dirnya. Optimisme berupa rasa pantang menyerah dan rasa semangat kerja.

a. Lagu Mahakarya

Lagu Mahakarya merupakan lagu yang tercipta dari pesan orang tua Tulus. lirik lagu Mahakarya ini merupakan tanda yang mewakili interpretan dari Tulus mengenai objek yang dilihatnya, yaitu tentang kerja keras. Makna di balik pesan yang disampaikan oleh Tulus dalam lagu Mahakarya ini merupakan sebuah motivasi untuk semua orang yang mendengarkan bahwa dalam melakukan usaha apapun itu bentuknya harus dilakukan dengan sepenuh hati karena kita tak pernah tau usaha mana yang akan mengantarkan pada sebuah keberhasilan. Selain itu usaha yang dilakukan dengan sepenuh hati akan melahirkan kebaikan. Kebaikan itu bukan hanya dirasakan oleh diri sendiri tapi juga orang lain di sekitar kita.

Lagu Mahakarya ini adalah bagian dari perjalanan hidup Tulus. Ketika itu kedua orang tua berpesan "Hidup itu tidak boleh bergantung pada peruntungan yang membuat lita bisa hidup atau tidak hidup adalah kerja keras karena semnua orang dilahirkan dengan kesempatan yang sama.” Ucap Tulus saat wawancara bersama EFLASH, dari pesan inilah yang selalu dipegang oleh Tulus hingga sekarang. Pesan yang membuatnya harus bekerja keras dalam mewujudkan mimpi-mimpinya sebagai seorang penyanyi dan pencipta lagu. Rintangan-rintangan dalam mewujudkan mimpinya telah Tulus rasakan saat sejak keil hingga setelah lulus kuliah

b. Lagu Manusia Kuat

Jiwa merupakan bagian terpenting di dalam diri individu yang berbentuk abstrak. Dari dalam jiwa semua terbentuk, seperti kekuatan, kelemahan, dll. Kekuatan pada jiwa dapat mengantarkan seseorang untuk terus melangkah maju dalam kehidupan. Kekuatan jiwa inilah yang coba digambarkan pada lagu Manusia Kuat.

Lagu Manusia Kuat merupakan bagian dari pengalaman Tulus dalam mencapai keinginannya sebagai penyanyi dan penulis lagu. Berawal dari masa kecil Tulus yang mendapatkan bullying dari teman-temannya dan 
dipandang sebelah mata akan karya-karya yang diciptakannya. Dari pengalaman-pengalaman pahit inilah Tulus bangkit karena kekuatan jiwa yang ada pada dirinya. Bahwa tak ada manusia lain yang dapat menghalanginya dalam meraih apa yang ingin dituju.

Kekuatan jiwa ini yang mendorongnya untuk terus dan terus berusaha mencapai impiannya, walau rintangan siap menghadangnya. Namun, kekuatan jiwanya jauh lebih kuat dibanding rintangan itu sendiri. Dari kekuatan jiwa inilah Tulus dapat menciptakan karya-karya yang tak dapat dinilai dengan sebelah mata saja. Karya-karyanya merupakan wujud idealis dari seorang Tulus yang terinspirasi dari cerita-cerita temannya, kisah perjalanan hidupnya, dan hasil pemikirannya sendiri.

Nilai optimisme yang disampaikan Tulus dalam lagu ini, yaitu optimisme yang harus dimiliki oleh setiap orang untuk pantang menyerah. Nilai optimisme ini berasal dari kekuatan jiwa. Adanya nilai optimisme pada diri membuat seseorang pantang menyerah dalam menghadapi dan menjalani suatu kesulitan di kehidupannya. Nilai optimisme tersebut menjadikan seseorang dapat melihat segala sesuatu hal ke arah positif, sehingga dapat menyelesaikan hal-hal yang menghadangnya.

c. Lagu Lekas

Pantang menyerah adalah salah satu sikap optimisme dalam menjalani kehidupan. Rasa pantang menyerah ini yang menjadi inspirasi Tulus dalam membuat lagu lekas. Lagu Lekas merupakan lagu yang menjadi soundtrack film “3 Nafas Likas” karya sutradara Rako Prijanto. Melalui lagu ini Tulus mengajak semua orang, khususnya pendengar lagu ini untuk terus melangkah dan berjuang dalam meraih sesuatu yang diinginkan, walaupun keadaan tak mendukung.

Pada lagu Lekas menjadi salah satu cara Tulus dalam mempersilakan siapa pun yang merasakan kesedihan dengan menangis agar hati sedikit tak terbebani, tetapi jangan biarkan diri terus meratapi kesedihan itu. Tulus mencoba menjelaskan bahwa setiap orang memiliki permasalahan dalam hidupnya, dan dari permasalahan tersebut diri harus belajar dan terus belajar untuk menjadikan semua berakhir dengan kebahagiaan. Jika diri terus larut 
dalam kesedihan takkan dapat mengubah semua yang telah terjadi, denga itu diri harus belajar memperbaiki kesalahan tersebut. Terus melangkah dan menghadapinya merupakan suatu langkah yang baik untuk membawa diri pada tujuan hidup. Nilai motivasi dalam lagu ini adalah rasa pantang menyerah. Rasa pantang menyerah ini akan mendorong seseorang untuk terus bangkit dari keterpurukan dalam hidupnya.

Pada tabel 3, dua lagu mengandung nilai motivasi dalam bentuk empati. Empati adalah sikap menempatkan diri pada posisi orang lain, sehingga dapat merasakan emosi dan pemikiran orang lain dan menciptakan keinginan untuk menolong. Saleh (2012: 225) mengatakan bahwa empati adalah suatu sikap dalam menempatkan diri pada suasana orang lain. Empati berupa rasa menghormati dan menghargai hak-hak orang lain serta penilaian dari sudut pandang berbeda. Dua lagu di album Monokrom yang terdapat nilai motivasi bentuk empati, yaitu lagu Tukar Jiwa dan Ruang Sendiri.

a. Lagu Tukar Jiwa

Interpretan Tulus dalam melihat objek berupa rasa empati, ia sampaikan pada lirik-lirik di lagu Tukar Jiwa yang berfungsi sebagai tanda. Pesan yang ingin disampaikan tentang pentingnya sebuah rasa empati, yaitu dengan menghargai dan menghormati pandangan orang lain mengenai penilaian tentang sesuatu hal karena setiap orang memiliki cara yang berbeda-beda dalam menilai. Dengan adanya rasa empati setiap orang termotivasi untuk menghargai cara pandangan dan penilaian orang lain, diri dapat merasakan dan mengetahui bagaimana melihat sesuatu hal atau permasalahan dari sudut yang berbeda. Rasa menghargai akan menumbuhkan rasa empati antar sesama. Rasa empati merupakan sebuah perasaan yang ikut merasakan bagaimana perasaan orang lain menanggapi sesuatu hal.

b. Lagu Ruang Sendiri

Setiap orang memiliki hak privasinya masing-masing, dan orang lain tidak dapat melanggar hal itu. Hubungan antara interpretan dari sudut pandang Tulus dengan objek berupa nilai empati yang diaplikasikan pada tanda, yaitu lirik lagu. Pada lagu ini Tulus mencoba memberikan solusi 
dalam memahami dengan orang lain, terutama menghargai dan menghormati hak orang lain. Solusi itu berupa motivasi terhadap individu untuk berempati pada orang lain. Dengan memberikan ruang sendiri bagi setiap individu, dengan begitu kita telah menghargai privasinya. Adanya ruang sendiri individu dapat secara pribadi menilai, merasakan, dan mengevaluasi dirinya sendiri, individu lain, dan hal-hal yang lainya.

Ruang sendiri adalah ruang untuk merenung, dalam lagu ini merenung akan hubungan antarsesama. Sebuah hubungan perlu adanya jarak yang dapat menimbulkan rindu, bila rindu tercipta dapat menjadikan individu dapat menilai seberapa berharga individu lain pada hubungan yang dijalani. Maka dari itu rasa empati ini harus ditumbuhkan dan dipelihara oleh setiap individu. Rasa empati ini berfungsi untuk menghargai privasi orang lain dan dapat mengurangi sebuah kecurigaan antarsesama. Namun, jika tidak adanya rasa empati antarsesama dapat menyebabkan privasi individu tidak diakui oleh pihak lain dalam suatu hubungan dan masyarakat.

\section{PENUTUP}

Berdasarkan data yang ada dapat disimpulkan bahwa menganalisis lagu dengan menggunakan teori semiotika model Charles Sander Peirce bahwa makna pesan nilainilai motivasi pada album Monokrom, yaitu tanda berupa lirik pada setiap lagu, objek berupa nilai motivasi, dan interpretan berupa pengalaman dan pemikiran Tulus dalam melihat kondisi sosial di sekitarnya. Nilai motivasi tersebut meliputi, 1) rasa cinta terhadap kedua orang tua dan pasangan tapi rasa cinta tak selamanya berbuah manis. Tak sedikit rasa cinta tersebut berbuah rasa kecewa karena di antara keduanya memiliki tujuan akhir yang berbeda dalam menjalani sebuah hubungan kasih.2) rasa optimisme, rasa yang harus dimiliki dan ditumbuhkan semua orang dalam dirinya. Rasa optimisme ini yang akan membawa seseorang untuk tetap kuat dalam menjalani kehidupan ini. 3) rasa empati terhadap orang lain dengan cara menghargai dan menghormati hak dan cara pandang mereka dari sisi yang berbeda.

\section{DAFTAR RUJUKAN}

Barthes, Roland.. 2010. Imaji Musik Teks. Yogyakarta: Jalasutra. 
Effendy, Onong Uchjana. 2009. Ilmu Komunikasi Teori dan Praktek. Bandung: PT Remaja Rosdakarya.

Eriyanto, 2001. Analisis Wacana.: Pengantar Analisis Teks Media. Yogyakarta:LkiS.

Ghufron, M. Nur dan Rini Risnawati. 2010. Teori-Teori Psikologi. Yogyakarta: Arruzz Media Group.

Krisyanto, Rachmat. 2009. Teknik Praktis Riset Komunikasi. Jakarta: Penerbit Kencana Prenada Media.

Mahsun. 2012. Metode Penelitian Bahasa :Tahapan Strategi, Metode, dan Tekniknya. Jakarta: Rajawali Pers.

Sobur, Alex. 2013. Psikologi Umum dalam lintasan sejarah. Bandung: CV Pustaka Setia.

Sugiono. 2015. Metode Penelitian: Kuantitatif, Kualitatif, dan R\&D. Bandung: Alfabeta. 